Research Article

\title{
Phytochemical Screening of Neem and Black Pepper for Bioefficacy against Insect Pests of Okra and Potato
}

\author{
Bushra Baig and Saeeda Yousaf* \\ Department of Environmental Sciences, University of Peshawar, Khyber Pakbtunkhwa, Pakistan.
}

\begin{abstract}
The efficacy of botanical insecticides i.e. Neem and Black pepper were evaluated against the insect pests (whitefly and aphid).The methanolic extracts of Black pepper and Neem were analyzed for identification of phytochemicals by using Gas Chromatography-Mass Spectrometry. The result showed that Alkaloids, Flavonoids, Tannins, Terpenoids and Phenolic compounds were found both in Black pepper and Neem.Quantitative analysis indicated 21 active componentsin Black pepper which were dominated byCaryophyllene (32.3\%), Delta-3-carene (18.7\%) and Cinene(15.5\%). Neem showed 17 active components, among them Beta-Pinene (14.8\%), Delta-Elemene (14.4\%) and Palmitic acid (13.2\%) were dominant. The mix-biopesticide of Black pepper and Neem in comparison to their individual impact showed the highest insecticidal efficacy against whitefly and aphids. The plots sprayed with mix-biopesticide showed the highest yield of okra and potato crops along with a healthier plant growth. The highest yield of Okra $(52 \mathrm{~kg})$ and Potato $(272 \mathrm{~kg}$ )and their plant growth was recorded in plots sprayed with mix-biopesticides. It is concluded that biopesticide from these two plants could be utilized for their efficacy against various pests of okra and potato. Keeping the environmentally friendly nature of these biopesticide, compared to synthetic pesticides, it is recommended that more research be directed for assessment of more active compounds that could act as potential candidates for biopesticide. The objective of the study was to find the bioactive compounds in plant extracts of Neem and Black pepper and their effectiveness against reduction in number of whitefly and aphids.

Received | March 01, 2021; Accepted | May 03, 2021; Published | June 09, 2021

*Correspondence | Saeeda Yousaf, Department of Environmental Sciences, University of Peshawar, Khyber Pakhtunkhwa, Pakistan; Email: saeeda@uop.edu.pk

Citation | Baig, B. and S. Yousaf.2021. Phytochemical screening of neem and black pepper for bioefficacy against insect pests of okra and potato. Sarhad Journal of Agriculture, 37(2): 697-705.

DOI | https://dx.doi.org/10.17582/journal.sja/2021/37.2.697.705

Keywords | Biopesticides, Phytochemicals, Black pepper, Neem, Whitefly, Aphid
\end{abstract}

\section{Introduction}

$\mathrm{O}$ $\mathrm{kra}$ (Abelmoschusesculentus L.) is an important vegetable crop cultivated in warm temperate, tropical and subtropical areas of the world (Kavianpour et al., 2014). It is an ample source of water, fiber, fat, protein, carbohydrate, thiamine, riboflavin, nicotinamide, ascorbic acid calcium, iron, and energy (Petropoulos et al., 2018). Insect pests, fungi, bacteria and plant viruses are the main causes of worldwide decrease in okra yield (Ghosal et al., 2013). Around 72 species of insect pests have been reported that attack okra crop in Pakistan (Rahman et al., 2013). Whitefly (Bemis tatabaci Genn.) is a sucking pest that damages okra by sucking the cell sap and secreting honeydew on the leaves (Kunjwal and Srivastava, 2018).

Potato (Solanum tuberosum) is the fourth most important crop in terms of production in Pakistan. Potato reveals a portion of 42 kilograms per person each of the yearly diet plans in some nations (FAO, 2010). It is attacked by various pests including aphids, 
potato leafhopper and fungi (Davis and Radcliff, 2008). Aphids (Aphidoidea) are the soft-bodied pests that cause damage to the plant directly by extracting sap of the plant foliage and indirectly as carrier of viral diseases (Yankova et al., 2008; Morita et al., 2007). The viruses spread through aphids causing degeneration of seed stocks and yield reduction of potato by 40 to $80 \%$ (Khurana, 2002). The common procedures used to control whiteflies and aphids are synthetic insecticides; however, these practices badly affect the agro-ecosystems, biodiversity, and useful organisms, while enhancing the genetic resistance of pests against pesticides. Therefore, searching effective, low risks and environment friendly management programs are necessary (Ibrahim et al., 2016).

Currently, using secondary metabolites of plants (alkaloids, phenols and terpenoids) as have been recognized as an effective bio-pesticides against pests with low environmental impacts (Celis et al., 2008). This study is aimed at investigating the phytochemicals of neem and black pepper and their bioefficacy against whitefly (feeding on okra crop) and aphids (feeding on potato crop).

\section{Materials and Methods}

\section{Experimental site and sampling}

The experimental work of this study was conducted at the Nuclear Institute for Food and Agriculture (NIFA). NIFA is established in 1982, located in Nowshera Khyber Pakhtunkhawa. The institute works for the enhancement of crop production and protection, soil fertility, water management and conservation and value addition of food resources, employing nuclear and other contemporary techniques. The seeds of Black pepper were purchased from the native market of Peshawar and Neem leaves were collected from the fields of NIFA. The target plant parts were collected, washed and shaded-dried.

\section{Preparation of plant extract}

The dried leaves of Neem and seeds of Black pepper were separately ground into a fine powder with the help of pestle and mortar. A 10\% stock solution of each plant extract was prepared by mixing 100 $\mathrm{g}$ powder of plant in $400 \mathrm{ml}$ of methanol. The powdered plant and methanol slurry were shaken in a mini orbital shaker for 3 hours at $260 \mathrm{rpm}$ and then passed through Buchner funnel with Whatman No. 1 filter paper for elimination of insoluble material. The methanol fraction was separated and air-dried.
The filtrate was then mixed in water in a conical flask in order to create an ultimate volume of one liter. The mixture was deeply shaken and remained for 24 hours, and thereafter, filtered through muslin cloth to remove impurities.

\section{Phytochemical screening}

Analysis of phytochemical of crude extract obtained from neem and black pepper was carried out according to the standard methods as suggested by Trease and Evans (Tiwari et al., 2011). Crude extracts of neem and black pepper were analyzed for phytochemicals such as tannins, alkaloid, steroid, phenols, glycosides, terpenoid and flavonoid.

\section{Gas chromatography mass spectrometry analysis}

To find the bioactive compound in the extracts and their quantification, it was further analyzed by $\mathrm{GC} /$ Ms. The various crude extracts of the plants were analyzed by using a (Shimadzu, 2010) equipped with a splitless mode injector system, EI detector and a TRB 5 MS capillary column with $0.25 \mathrm{~mm}$ internal diameter, $0.25 \mathrm{um}$ motionless film thickness, and $30 \mathrm{~m}$ length produced from Phenomenex was utilized for verification of biopesticide. For the first time, the temperature for oven was set at $50^{\circ} \mathrm{C} / \mathrm{min}$, after it was programmed in the range of $25^{\circ} \mathrm{C} / \mathrm{min}$ to $125^{\circ} \mathrm{C} /$ min and then from $125^{\circ} \mathrm{C}$ to $300^{\circ} \mathrm{C}$ with the rate of $10^{\circ} \mathrm{C} / \mathrm{min}$ and at the end sustained for 15 minutes. The minimum detection limit of GC-MS for the determination of pesticide was $0.1 \mathrm{ppb}$. The total time for one GC run was $36.5 \mathrm{~min}$. Other conditions set for operations were ultra unblended helium moved through molecular sieve artifice and oxygen that was trapped was utilized as the carrier gas at the steady linear velocity of $40.7 \mathrm{~cm} / \mathrm{sec}$. The noted temperature of injection port was $250^{\circ} \mathrm{C}$ and utilized in combined at ratio of 10:00. The detector temperature was set at $280{ }^{\circ} \mathrm{C}$ with column flow $1.22 \mathrm{ml} / \mathrm{min}$. The crude extract's percentage composition is shown as percentage by peak area (Area Normalization). Total GC running time was $30 \mathrm{~min}$. Interpretation on mass spectrum GC-MS was performed utilizing the database of national institute of standard and technology (NIST). The mass spectrum of unfamiliar constituent was compared with the spectrum of the known constituents stored in the NIST Library.

\section{Experimental design}

Two field experiments were performed during 2018 at the research field of NIFA. Two plants including okra 
and potato were selected for the experiment. The okra seeds were sown in April 18 ${ }^{\text {th }}, 2018$ and potato seeds were sown in October $3^{\text {rd }}, 2018$. Based on treatments each crop was separately cultivated in four plots. Each plot size for okra crop was kept 0.0309 acres, with 18 inches space between rows and 12 inches between plants. Similarly, each plot size for potato crop was kept 0.0587 acres, with a space of 24 inches between rows and 12 inches between plants. The four treatments (including control) were replicated three times in Randomized Complete Block Design (RCBD). The first plot of both crops was sprayed with Neem, second plot with Black pepper; third plot with a biocompound of both neem and black pepper and fourth plot was left as control. The comparative effectiveness of the biopesticides was based on the reduction in the whitefly and aphids which was noted after treatment intervals i.e.22 ${ }^{\text {nd }}, 43^{\text {rd }}$ days. The next spray was done after 15 days interval of the first spray.

\section{Preparation of Bio-pesticides}

Neem biopesticide was prepared by mixing $5 \%$ Neem leaves extract in $5 \mathrm{ml}$ NIFA-adjuvant and raise volume up to 10 liters in water. Similarly, 5\% Black pepper extract was taken in $5 \mathrm{ml}$ NIFA adjuvant and volumedupto10 liters of water. A 3.5\% Neem \% Neem extract and $1.5 \%$ Black pepper extract were mixed in $5 \mathrm{ml}$ of NIFA adjuvant and 10 liters of water. NIFA adjuvant is an organo-sulphur compound and acts as an emulsifier, spreader, sticker and stabilizer. This product remains stable for 3 years and can be mixed with water and used as pesticide efficacy enhancer.

\section{Observations recorded}

Population of sucking insects: The population of sucking insect pests was recorded in the morning time by leaves of five randomly selected plants of each plot. The first spray result was conducted on $22^{\text {nd }}, 23^{\text {rd }}$, $28^{\text {th }}$, and $42^{\text {nd }}$ days, and the second spray was checked on $43^{\text {rd }}, 44^{\text {th }}$ and $49^{\text {th }}$ day of crop germination which was presented in graphs.

\section{Crop growth and yield}

The yield and crop growth were the parameters considered to examine the impact of bio pesticides. The fruit of okra and potato was collected by the end of the time. The weight of picked up fruit in each plot was recorded. The height of plant, numbers of fruits, area of leaves were also taken as constraints for the evaluation of the effect of biopesticides on okra and potato.

\section{Statistical analysis}

Box plots were constructed using Sigma Plot 12.5 (Systa Software Inc., CA, and USA) (Dalal et al., 2015).

\section{Results and Discussion}

This study investigated phytochemical compounds extracted from the leaves of Neem and seeds of Black pepper for their insecticidal efficacy against whiteflies (on okra) and aphids (on potato), and their effect on selected crops' growth and productivity.

\section{Phytochemical screening of neem and black pepper}

The qualitative phytochemical analysis of methanolic extracts of black pepper and neem indicated the existence of phytochemical in varying proportions (Tables 1 and 2). Qualitative analysis showed presence of alkaloids, flavonoids, tannins, terpenoids and phenolic compounds both in black pepper and neem. Carbohydrates, reducing sugar and steroids were reported only from Neem, while protein and amino acids were detected in Black pepper.

Table 1: Qualitative assessment of phytochemical present in neem and black pepper.

$\begin{array}{lll}\text { Phytochemicals } & \text { Neem } & \text { Black pepper } \\ \text { Alkaloids } & + & + \\ \text { Carbohydrates } & + & - \\ \text { Saponins } & - & - \\ \text { Glycosides } & - & - \\ \text { Protein and Amino acids } & - & + \\ \text { Reducing sugar } & + & - \\ \text { Phenolic compounds } & + & + \\ \text { Flavonoids } & + & + \\ \text { Terpenoids/Steriods } & +/+ & +/- \\ \text { Tannins } & + & +\end{array}$

Biopesticidal efficacy of neem and black pepper against whitefly and aphids

The bio-pesticidal effects of Neem, Black pepper and their bio-compound (i.e. mixture of neem and black pepper) against the whitefly population on okra crop were investigated on $1^{\text {st }}$-spray and $2^{\text {nd }}$-spray stages. Both sprays of biopesticide mixture showed the highest efficacy against whitefly. After $1^{\text {st }}$-spraythe whitefly population was suppressed from 38.5 to $52 \%$ with an average of $46.8 \%$ on $22^{\text {nd }}$ day, and from 45.8 to $66.7 \%$ with an average of $58.8 \%$ on $23^{\text {rd }}$ day, and from 29.2 to $59.3 \%$ with an average of $43.6 \%$ on $28^{\text {th }}$ day,

June 2021 | Volume 37 | Issue 2 | Page 699 
Table 2: Quantitative determination of bioactive components in black pepper seeds and neem plant.

\begin{tabular}{|c|c|c|c|c|c|c|c|}
\hline \multicolumn{4}{|c|}{ Black pepper } & \multicolumn{4}{|c|}{ Neem } \\
\hline Phytochemicals & $\begin{array}{l}\text { Concentra- } \\
\text { tion }(\%)\end{array}$ & RT & Area & Phytochemicals & $\begin{array}{l}\text { Concentra- } \\
\text { tion (\%) }\end{array}$ & RT & Area \\
\hline 3-Carene & 7.85 & 3.574 & 977 & 4-Cymene & 3.38 & 3.56 & 148190 \\
\hline Delta-3-carene & 18.7 & 3.655 & 2325 & Beta-Pinene & 14.8 & 3.617 & 646746 \\
\hline Alpha-Limonene & 1.23 & 3.828 & 155 & dl-Limonene & 10.7 & 3.888 & 465723 \\
\hline Cinene & 15.5 & 3.903 & 2312 & Delta-terpinene & 5.95 & 4.008 & 260897 \\
\hline Beta-Linalool & 1.33 & 5.049 & 165 & Beta-Caryophyllene & 2.47 & 5.04 & 108037 \\
\hline Delta-Elemene & 11.7 & 10.1 & 1454 & Delta-Elemene & 14.4 & 10.087 & 635110 \\
\hline Ylangene & 0.42 & 10.42 & 52 & Beta-Germacrene & 0.72 & 10.384 & 31685 \\
\hline Copaene & 6.27 & 11.048 & 781 & Tri-decylic acid & 10.3 & 11.031 & 451899 \\
\hline Levo-beta-Elemene & 1.22 & 11.39 & 152 & Caryophyllene oxide & 2.48 & 11.373 & 108456 \\
\hline Caryophyllene & 32.3 & 12.117 & 4019 & Alpha-Cadinol & 3.08 & 12.058 & 135070 \\
\hline Alpha Caryophyllene & 7.06 & 12.919 & 878 & Palmitic acid & 13.2 & 12.899 & 579089 \\
\hline Alpha-Curcumene & 0.56 & 13.473 & 83 & 13-Octadecanoic acid methyl ester & 3.66 & 13.461 & 160515 \\
\hline Eudesma-4(14),11-diene & 0.75 & 13.684 & 93 & Phytol & 0.25 & 13.509 & 10792 \\
\hline Alpha-Selinene & 0.56 & 13.879 & 69 & Methyl stearate & 0.5 & 13.665 & 22266 \\
\hline Beta-Bisabolene & 0.43 & 14.104 & 53 & Pentacosane & 0.74 & 14.087 & 32137 \\
\hline Delta-Cadinene & 2.33 & 14.441 & 290 & (-)-Spathulenol & 5.51 & 17.063 & 285927 \\
\hline Caryophylleneoxide & 1.11 & 15.953 & 138 & Ar-tumerone & 7.43 & 17.685 & 326294 \\
\hline Myristyl chloride & 0.61 & 16.049 & 76 & & & & \\
\hline Ledol & 0.097 & 16.558 & 12 & & & & \\
\hline (-)-Spathulenol & 3.7 & 17.044 & 460 & & & & \\
\hline Ar-tumerone & 3.66 & 17.74 & 455 & & & & \\
\hline
\end{tabular}

RT: Retention time.

and from a decrease of $4.4 \%$ to an increase of $-2.9 \%$ with an average of $4.1 \%$ on $42^{\text {nd }}$ day. After $2^{\text {nd }}$ spray the whitefly population decreased from $59.4 \%-69.7 \%$ with an average of $63.7 \%$ on $43^{\text {rd }}$ day, and from 64.7 to $76.3 \%$ with an average of $72 \%$ on $44^{\text {th }}$ day and from 61.8 to $68.6 \%$ with an average of $64.2 \%$ on $49^{\text {th }}$ day after crop sowing.

Biopesticides of neem and black pepper showed almost similar highest effect against whiteflies on both sprays. Neem biopesticide produced a reduction of whitefly population from 25 to $42.3 \%$ with an average of $33.1 \%$ on $22^{\text {nd }}$ day, and from 29.2 to $41.7 \%$ with an average of $35.6 \%$ on $23^{\text {rd }}$ day, and from 29.6 to $37.5 \%$ with an average of $32.6 \%$ on $28^{\text {th }}$ day, and from $9.4 \%$ to an increase of $-2.9 \%$ with an average of $4.2 \%$ on $42^{\text {nd }}$ day, and from 51.7 to $66.7 \%$ with an average of $60.3 \%$ on $43^{\text {rd }}$ day, and from 64.7 to $71.1 \%$ with an average of $68.2 \%$ on $43^{\text {rd }}$ day, and from 52.9 to $62.2 \%$ with an average of $58.4 \%$ on $49^{\text {th }}$ day.

Black pepper biopesticide reduced whitefly population from 32 to $34.6 \%$ with an average of $33.3 \%$ on $22^{\text {nd }}$ days, and from 29.2 to $37.5 \%$ with an average of $34.2 \%$ on $23^{\text {rd }}$ days, and from 25 to $40.7 \%$ with an average of $33.5 \%$ on $28^{\text {th }}$ days, and from 0 to $9.1 \%$ with an average of $4.1 \%$ on $42^{\text {nd }}$ days, and from 48.3 to $62.5 \%$ with an average of $56.1 \%$ on $43^{\text {rd }}$ days, and from 60.5 to $65.6 \%$ with an average of $63.6 \%$ on $43^{\text {rd }}$ days, and from 48.6 to $56.8 \%$ with an average of $52.8 \%$ on $49^{\text {th }}$ days.

The bio-pesticides of black pepper, neem and their mix showed substantial insecticidal effect against aphids on potato on both $1^{\text {st }}$-spray and $2^{\text {nd }}$-spray (Table 2). The mixed bio-pesticide spray indicated the highest Insecticidal effect against aphids. After $1^{\text {st }}$ spray, the aphids population reduced from 40 to $60.7 \%$ with an average of $50.2 \%\left(22^{\text {nd }} \mathrm{day}\right)$, and from 60 to $75 \%$ with an average of $69.7 \%$ (23rd day), from 36 to $60.7 \%$ with an average of $48.2 \%$ ( $28^{\text {th }}$ days), and from $0 \%$ to an increase of $-6.8 \%$ ( $42^{\text {nd }}$ days $)$. After $2^{\text {nd }}$ spray, the aphids population decreased from 61.1 to $75.6 \%$ with an average of $69.1 \%$ ( $43^{\text {rd }}$ days), and from 71.8 to 
$85.7 \%$ with an average of $78.8 \%$ ( $44^{\text {th }}$ days), and from 2 to 2.6 with an average of 2.3 ( $49^{\text {th }}$ days). Neem and black pepper sprays showed almost similar effects. On average, 1st-spray of Neem biopesticides reduced the aphid's population by $50.4,63.2,43.8$, and $4.3 \%$ on $22^{\text {nd }}, 23^{\text {rd }}, 28^{\text {th }}$ and $42^{\text {nd }}$ days, respectively. Likewise, the $2^{\text {nd }}$-spray reduced the aphid's population by 67.4 , 67 , and $54.7 \%$ on $43^{\text {rd }}, 44^{\text {th }}$ and $49^{\text {th }}$ days, respectively. Similarly, $1^{\text {st }}$-spray of Black pepper biopesticide reduced the aphid's population by $45.7,54.7$, and 39.6 and $5.1 \%$ on $22^{\text {nd }}, 23^{\text {rd }}, 28^{\text {th }}$ and $42^{\text {nd }}$ day, respectively; while, the $2^{\text {nd }}$-spray reduced their population by 63.9 , 67.2 and $52.9 \%$ on $43^{\text {rd }}, 44^{\text {th }}$ and $49^{\text {th }}$ day, respectively.

\section{Plant height of okra and potato $(\mathrm{cm})$}

A remarkable variation was observed in plant height with different treatments. The data showed that in okra plant the hight plant height ranged from 148-152.1 $\mathrm{cm}$ with an average of $149.9 \mathrm{~cm}$ in bio compound of neem and black pepper treated plots. The plant height in Neem biopesticide treated plot ranged from 147$150.2 \mathrm{~cm}$ with an average of $148.8 \mathrm{~cm}$. Plant height in Black pepper biopesticide treated plot ranged between $143.2-147 \mathrm{~cm}$ with an average of $145.5 \mathrm{~cm}$; while the hight plant height of potato plants ranged between 34-35.1 with $34.7 \mathrm{~cm}$ in biocompound of neem and black pepper treated plots. The plant height in Neem biopesticide treated plot ranged from 34$35 \mathrm{~cm}$ with an average of $34.3 \mathrm{~cm}$. In Black pepper biopesticide treated plots, plant height ranged from $30-33.2 \mathrm{~cm}$ with an average of $32 \mathrm{~cm}$.

\section{Number of fruits of okra and potato per plant}

The results revealed that considerable number of fruits per plant of okra was observed in biocompound of neem and black pepper treated plots. The number of fruits of okra plant ranged from 15-19 with 17.7 as an average value. The number of fruits of okra plant in neem biopesticide treated plots ranged from 14-18 with an average of 16.7. In black pepper biopesticide
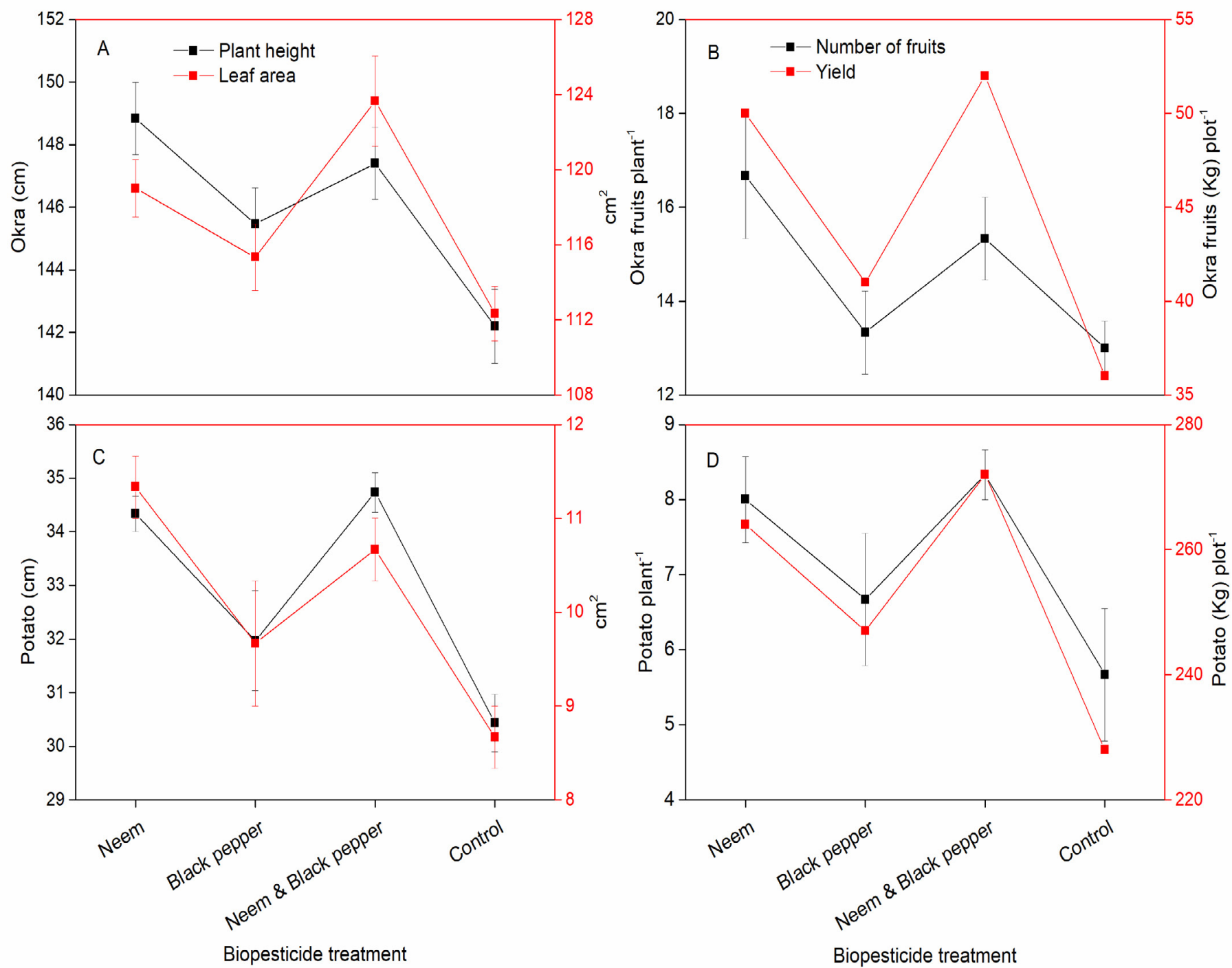

Figure 1: Biopesticidal effect on productivity. 
treated plots, the number of fruits of okra plant ranged from 13-15 with an average of 13.7.In Potato plants, results showed that the highest number of fruit per plant was in biocompound of neem and black pepper treated plots with the range of values between 8.0-9.0, averaged at 8.3.The number of fruit of potato plant in Neem biopesticide treated plots ranged between 7.0 and 9.0 with an average of 8.0. In Black pepper treated plots, the number of fruits of potato plant ranged from 5-8 with an average of 6.7.

\section{Leaf area of okra and potato $\left(\mathrm{cm}^{2}\right)$}

The results exhibited that the highest leaf area of okra plant was found in biocompoud of neem and black pepper treated plots, where the leaf area ranged from $119-127 \mathrm{~cm}^{2}$ with an average of $123.6 \mathrm{~cm}^{2}$. In Neem biopesticide treated plots, the leaf area ranged from $116-121 \mathrm{~cm}^{2}$ with an average of $119 \mathrm{~cm}^{2}$. Next to them was Black pepper biopesticide treated plots where leaf area ranged from $112-118 \mathrm{~cm}^{2}$ with an average of $115.3 \mathrm{~cm}^{2}$. In potato plants, the results revealed that the highest leaf area was observed in biocompound of neem and black pepper treated plots that ranged between $11-12 \mathrm{~cm}^{2}$ averaged as $11.3 \mathrm{~cm}^{2}$. The leaf area in Neem biopesticide treated plots ranged from 10$11 \mathrm{~cm}^{2}$ with an average of $10.6 \mathrm{~cm}^{2}$.Next to them was Black pepper treated plots, the leaf area ranged from $9-11 \mathrm{~cm}^{2}$ with an average of $9.66 \mathrm{~cm}^{2}$.

\section{Yield of okra and potato $\mathrm{kg}$ per plot}

The data regarding yield revealed that there was highly difference between the yields of all plots. The yield was comparatively more in plots managed with plant extracts than the control plots. In okra field, the highest yield of $52 \mathrm{~kg}$ per plot was observed in the plot dealt with neem and black pepper biocompound. Neem biopesticide showed yield of $50 \mathrm{~kg}$ followed by Black pepper biopesticide yield $(41 \mathrm{~kg})$. The minimum production of $36 \mathrm{~kg}$ was noted in control plots. In potato field, the highest yield of $272 \mathrm{~kg}$ was also observed in the plots treated with biocompound of neem and black pepper. Neem biopesticide showed yield of $264 \mathrm{~kg}$ and Black pepper showed yield of 247 $\mathrm{kg}$. However, the lowest yield of $228 \mathrm{~kg}$ was noted in control plot.

\section{Phytochemical screening of neem and black pepper}

In the present study, phytochemical screening of neem and black pepper were used for the efficacy of okra and potato production. The result revealed that all the phytochemicals were present in the plant extracts. The ten phytochemicals were screened included alkaloids, flavonoids, tannins, and phenolic compounds. They were extracted from both plant extracts. Qualitative analysis results confirmed the absence of saponins,tannins,terpenoids,steroids,carbohydrates, alkaloids, and flavonoids; while phenolic compounds were present in the organic extracts of Neem. Prashanth and Krishnaiah (2014) observed alkaloid, reducing sugar, flavonoid, tannins and saponin in Neem. Vinoth et al. (2012) studied phytochemical analysis of Neem leaves by applying various solvents such as methanol, ethanol and acetone revealed the occurrence of reducing sugar, flavonoids, tannins and saponin. The photochemical like carbohydrates, protein, alkaloids and phenolic compounds were absent. Maximum number of phytochemicals was present in Black pepper extract like alkaloids, flavonoid, tannins, proteins, phenols and phytosterols. Similar observations were reported by (Zahira et al., 2016), while terpenoids and saponin were absent though terpenoids were present in this study. Nahak and Sahu (2011) stated the occurrence of alkaloids, glycosides, tannins, phenol,essential oil and protein in Black pepper extract.

\section{Effect of bio-pesticides}

The results showed that the use of plant extracts alone or in combination as biopesticides was highly effective against whitefly and aphids. In the present experiments after thorough investigations, indicated that application of plant extracts in combinations performed better results than alone. Comparatively, the mix-biopesticide showed the highest insecticidal efficacy against both pests (Mix > Neem > Black pepper). Indicating that a specific proportion of two or more plants extract in a biopesticide could have high insecticidal properties than an individual one. All three biopesticides treatment indicated a prominent decrease in whitefly and aphids population during the first week of $1^{\text {st }}$-spray (i.e. from $22^{\text {nd }}-28^{\text {th }}$ day of crop cultivation. However, on the $20^{\text {th }}$ day of $1^{\text {st }}$ spray (i.e. at $42^{\text {nd }}$ day of crop cultivation), minimum reduction or increase in both pests population was observed. This indicates that long spray intervals provide opportunity for pests to grow or restore their population. However, at $2^{\text {nd }}$-spray (conducted on $43^{\text {rd }}$ days) both pests population again substantially declined. This indicates biopesticides efficiently work against pests and should be consistently sprayed once in a week. Further, that Biopesticides didn't lose the efficacy against pests and worked well by continuous spraying. 
Our results indicated that neem and black pepper showed 10-20\% high insecticidal efficacy against aphids than whitefly at $1^{\text {st }}$ spray, while almost equal insecticidal efficacy during second spray against both pests. However, mix-biopesticide indicated 4-10\% high efficacy at both sprays against aphids than whitefly. Collectively, all three biopesticides worked with high efficiency against aphids than whitefly. The result of study showed non-significant differences among treatment. Ali et al. (2015) concluded that joint consumption of biopesticides ( $M$. Oeifara + A.Indica $+E$. globolous) at $50 \%$ concentration is very effective against wheat aphid and synergistic effect of these plants is higher as compared to using them alone. Among the selected plants, neem and black pepper are often considered as the most promising bioactive (Gorgani et al., 2017; Reshmi et al., 2010). It effectively helped in reduction of population of jassid, whitefly, and thrips (Kumar et al., 2019). Neem has shield power to harm chemoreceptors which prevent insects from feeding. Neemalso plays an important role in reducing fertility in pests and insects while being one of the greatest repellents; acts as larvicidal and prevents egg hatching.

The results of the study (Lawal et al., 2010) have observed that aqueous Neem seed extract is beneficial in increasing plant growth and yield parameters. According to (Nzanza et al., 2011). Neem oil @ 3\% and also garlic bulb extract $10 \%$ possess insecticidal homes to keep reduced demography of whitefly and also insect on plus all aspect of neem include unsweetened material.

The biocompound of neem and black pepper was very effective in increasing the yield of okra and potato plant. The Neem plant has nutrients such as nitrogen which will faster vegetative growth and development of the fruits. Neem leaves behind essence, possesses higher market value of nitrogen and phosphorus as well as improves the fallen leave place, vegetation level, stem size and seeds of crops.A plant growthrise was observed in biocompound of neem and black pepper along with Neem biopesticide. Ahmad et al. (2002) reported that foliar application of Neemoil and synergistic compound of Neem oil and bifenthrin resulted in increasing the overall yield, leaf area and shoot length and can be used as a pest control. Nahak and Sahu (2011) studied that Neem leaves extract act as potential source for the management of severe diseases and furthermore it has a positive effect on growth parameters. The Neem extract improved shoot elevation, number of leaves, variety of flowers and production of tomato vegetation. (Moyin-Jesu, 2010) stated that neem leaves behind essence, possesses higher market value of nitrogen and also phosphorus as well as to improve the fallen leave place, vegetation level, stalk circumference and also seeds of maize. Mahmood et al.(2014) who reported that biopesticides consisting of Azadirachta indica, Nicotiona tabacum as well as to a lesser degree Asafeotida were effective in controlling okra pests by causing the minimum losses to environment, beneficial insects and also okra agroecosystem.

\section{Conclusions and Recommendations}

Biopesticides are naturally derived materials used in the control of plant pests and diseases which are safer than chemical pesticides. Synthesis of biopesticides by using plant and their extracts is very cost-effective process. This research was focused on neem and black pepper extracts having insecticidal activity against selected pests. The study has revealed the presence of phytochemicals considered as active chemical constituents. Neem and black pepper extract indicated the presence of glycosides, saponins, alkaloids, tannins, flavonoids and phenolic compounds. Biocompound of neem and black pepper should be used in controlling whitefly and aphids. Collectively, all three biopesticides work with high efficiency against aphids and whitefly. Utilization of these natural products in place of old insecticides can eliminate environmental threats, maintain non-target insects and prevent insecticide-induced pest revival. These natural products could be utilized alone or even in blend along with various other weeds, thus enhance the insecticidal effectiveness.

\section{Novelty Statement}

The Novelty of this study is that adjuvant compound of Neem and Blackpepper should be used in controlling pests (Aphids and Whitefly), for increasing productivity rate of Okra and Potato.

\section{Author's Contribution}

Bushra Baig: Principal Author, conducted the research, analyzed the data and wrote the draft of the manuscript.

Saeeda Yousaf: Supervised the whole research study. 
Conflict of interest

The authors have declared no conflict of interest.

\section{References}

Ahmad, G., S.A. Malik, Z. Mahmood, M.Z. Iqbal and S. Ahmad. 2002. Effect of cotton leaf curl disease severity on morphology, yield and fibre characteristics of susceptible lines/ cultivars of cotton ( $G$. hirsutum L.). Asian. J. Plant Sci., 1: 705-707. https://doi.org/10.3923/ ajps.2002.705.707

Ali, H., M. Qasim, H.S.A. Saqib, M. Arif and S.U. Islam. 2015. Synergetic effects of various plant

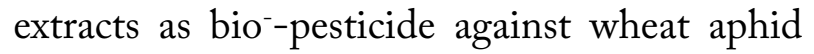
Diurophousnoxia L.) (Hemiptera: Aphididae). Afr.J.Agric. Sci.Tech.(AJAST), 3(7):310- 315.

Aslam, M. and S.N.H. Naqvi. 2000. Efficacy of phytopesticides in comparison with perfekthion against sucking pest of cotton. Turk. J. Zool., 24: 403-408.

Babatunde, R.O., O.A. Omotesho and O.S. Sholotan. 2007. Socio_economic characteristics and food security statusof farming household in Kwara State, North Central Nigeria, Pak. J. Nutr., 6: 1-16. https://doi.org/10.3923/ pjn.2007.49.58

Celis, A., C. Mendoza, M. Pachón, J. Cardona, W. Delgado and L. Cuca. 2008. Extract osfvegetables utilizados como biocontroladores con énfasis en la familia Piperaceae. Una revisión. Agron. Colomb., 26: 97-106.

Dalal, S.S., D.M. Walters, I. Lyubimov, J.J. de Pablo, and M.D. 2015. Tunable molecular orientation and elevated thermal stability of vapordeposited organic semiconductors. Proceed. Natl. Acad. Sci., 112(14): 4227-4232.

Davis, J.A., and E.B. Radcliffe. 2008. The importance of an invasive aphid species in vectoring a persistently transmitted potato virus: Aphis glycines is a vector of Potato leafroll virus. Plant Dis., 92(11): 1515-1523. https:// doi.org/10.1094/PDIS-92-11-1515

FAOSTAT, 2010. The FAO (Food and Agriculture Organization of the United Nations) Statistical Database. Data retrievedon.

Gulsen, O., S. Karagul and K. Abak, 2007. Diversity and relationships among Turkish okra germplasm by SRAP and phenotypic marker polymorphism. Biol. Brat., 62: 41-45. https:// doi.org/10.2478/s11756-007-0010-y
Ghosal,A.,M.L.Chatterjee and L.A.Bhattacharyya. 2013. Bio-efficacy of neonicotinoids against Aphis gossypi Glover of okra. J. Cro.Weed, 9: 181-184.

Gorgani, L., M. Mohammadi, G.D. Najafpour and M. Nikzad. 2017. Piperine the bioactive compound of black pepper from isolation to medicinal formulations. Compr. Rev. Food Sci. Food Saf., 16(1): 124-140. https://doi. org/10.1111/1541-4337.12246

Grainge, M. and S. Ahmed. 1988. Handbook of plants with pest-control properties. Resource systems institute, East-West center, Honolulu, Hawaii.

Harrison, B.D., Y.L. Liv, S. Khalid, S. Hameed, G.W. Otim Nape and D.J. Robinson., 1997. Detection and relationship of cotton leaf curl virus and allied white fly transmit Gemini viruses accruing in Pakistan. Annu. Appl. Biol., 130: 6175. https://doi.org/10.1111/j.1744-7348.1997. tb05783.x

Hill, D.S., 1983. Agricultural insect pests of the tropics and their control, Cambridge: Cambridge Univ. Press, $2^{\text {nd }}$ ed.

Ibrahim, M.A.A. and D.M. Morsy. 2016. Smart cities and sustainability: A set of vertical solutions for managing resources. Int.J. Environ. Sustain., 5(3):1-15.

Kavianpour,M.,G.R.Dabbagh,M.Taki,M.Shirdeli and S. Mohammadi. 2014. Effect of fresh gum of assafoetida on the damage reduction of pomegranate fruit moth, Ectomyelois ceratoniae (Lep., Pyralidae) in Shahreza City. Int.J. Biosci., 5 (5): 86-91

Khurana, S.M., 2002. Potato viruses and viral diseases. Central potato research institute: Shimla. Kausik B, Chattopadhyey IRK, Benerjee O, Bandyopdyey U.,2002. Biological activities Medicinal properties of neem. Curr. Sci., 82(11): 1336-1344.

Kumar, A., R. Ilavarasan, T. Jayachandran, M. Decaraman, P. Aravindhan, N. Padmanabhan and M.R. Krishman. 2019. Phytochemicals investigation on a tropical plant, Azadirachta indica Erode District, Tamil Nadu, South India. Pak. J. Nutr., 8(1): 83-85. https://doi. org/10.3923/pjn.2009.83.85

Kunjwal, N. and R.M. Srivastava. 2018. Insect pests of vegetables. In Pests and their Management. Springer, Singapore. PP. 163-221.

Lawal, A., S.M. Dangoggo and K.J. Umar. 2010. 
Phytochemical and antibacterial screening of garlic (Allium sativum). Katsina J. Pure Appl. Sci., 2(2): 101-104.

Mahmood, K., S. Eijaz, M.A. Khan, A. Alamgir, S.S. Shaukat, Z. Mehmood and A. Sajjad. 2014 .Effects of biopesticides against jassid [amrasca devastans (dist.)] and white fly [Bemisia tabaci (genn.)] on okra. Int. J. Biol. Biotechnol., 11(1): 161-165.

Morita, M., T. Ueda, T. Yoneda, T. Koyanagi and T. Haga.2007.Flonicamid, a novel insecticide with a rapid inhibitory effect on aphid feeding. Pest Mange. Sci. Formerly Pestic. Sci., 63(10): 969973. https://doi.org/10.1002/ps.1423

Morshed, S., M.D. Hossain, M. Ahmad and M. Junayed. 2017. Physicochemical characteristics of essential oil of black pepper (Piper nigrum) cultivated in Chittagong, Bangladesh. J. Food Qual. Hazard. Contr., 4(3): 66-69.

Moyin-Jesu, E.I., 2010. Comparative evaluation of modified neem leaf, neem leaf and wood ash extracts as pest control in maize (Zea mays $\mathrm{L}$ ). Emir. J. Food Agric., 22: 34-44. https://doi. org/10.9755/ejfa.v22i1.4905

Nahak, G. and R.K. Sahu. 2011. Phytochemical evaluation and antioxidant activity of Piper Cube.com.comba and Piper nigrum. J. Appl. Pharma. Sci., 1(8): 153-157.

Nzanza, B., D. Marais and P. Soundy. 2011. Tomato (Solanum lycopersicum L.) seedling growth and development as influenced by Trichoderma harzianum and arbuscular mycorrhizal fungi.

Petropoulos, F., N. Kourentzes, K. Nikolopoulos and E. Siemsen. 2018. Judgmental selection of forecasting models. J. Operations Mgt., 60: 3446.

Prashanth, G.K. and G.M. Krishnaiah. 2014. Chemical composition of the leaves of
Azadirachta indica Linn (Neem). Int. J. Adv. Eng. Tech. Manage. Appl. Sci., 1: 21-31.

Parthasarathy,N.,M.A.Selwyn andM.Udayakumar. 2008. Tropical dry evergreen forests of peninsular India: Ecology and conservation significance. Trop. Conser. Sci., 1(2): 89-110. https://doi.org/10.1177/194008290800100203

Priya, N.C. and K.C. Sarwana. 2016. Identification of classes of compounds ad estimitation of flavanoid and phenol from seeds of piper longum and piper $\mathrm{n}$ nigrum. Int. J. Pharma. Biol. Sci., 1(B): 593-601.

Rahman, M.M., M.M. Uddin and M. Shahjahan. 2013. Management of okra shoot and fruit borer, Earias vittella (fabricius) using chemical and botanical insecticides for different okra varieties. Int. Res. J. Appl. Life Sci., 2(1).

Reshmi, S., S.K. Reshmi, E. Sathya and P.S. Devi. 2010. Isolation of piperdine from Piper nigrum and its antiproliferative activity. J. Med. Plant Res., 4(15): 1535-1546.

Tiwari, P., B. Kumar, M. Kaur, G. Kaur and H. Kaur. 2011. Phytochemical screening and extraction: A review. Int. Pharma Sci., 1(1): 98-106.

Vinoth, B., R. Manivasagaperumal and M. Rajaravindran. 2012. Phytochemical analysis and antibacterial activity of Azadirachta indica A. Juss. Int. J. Res. Plant Sci., 2(3): 50-55.

Yankova, V., D. Markova, V. Todorova and G. Velichkov. 2008. Biological activity of certain oils in control of green peach aphid (Myzus persicae Sulz.) on pepper . In IV Balkan Symp. Vege. Potato. 830: 619-626. https://doi. org/10.17660/ActaHortic.2009.830.90

Zahira, A., K. Thamilmani and R.R. Mohamed. 2016. Phytochemical careening and gc-ms profiling of piper nigrum 1. World J. Pharma. Res., 5(5): 798-807. 